\title{
COMPARISON OF ECOTOXICITY OF NICKEL AND IRON OXIDES AND THEIR NANOFORMS
}

\author{
S. I. Kolesnikov*, A. N. Timoshenko, K. S. Kazeev, Y. V. Akimenko \\ and A. V. Soldatov \\ Southern Federal University, Stachki Avenue, 149/1, Rostov-on-Don, 344090, Russia \\ *E-mail: kolesnikov@sfedu.ru
}

\begin{abstract}
In the model experiment, the ecotoxicity of nanoparticles (10-20 nm) and conventional (non-nano) powders (100 $\mathrm{nm}$ and above) of $\mathrm{Ni}$ and $\mathrm{Fe}$ oxides was compared. Their effect on microorganisms, plants and enzymatic activity of the soil was investigated as well.

It was found that the microbiological indicators (the total number of bacteria and the abundance of Azotobacter) were most strongly affected by the nanoforms of $\mathrm{Ni}$ and Fe oxides. The enzymatic activity of the soil (the activity of catalase and dehydrogenase) was largely dependent on $\mathrm{Ni}$ and $\mathrm{Fe}$ oxides and not on their nanoparticles. The indicators of phytotoxicity (germination and length of the radish root) were influenced both by $\mathrm{Ni}$ and $\mathrm{Fe}$ oxides and their nanoforms in equal measure.

Thus, nanoparticles of $\mathrm{Ni}$ and $\mathrm{Fe}$ oxides (10-20 nm) are more toxic for bacteria than particles of $\mathrm{Ni}$ and $\mathrm{Fe}$ oxides of usual sizes (100 nm and above), and vice versa for soil enzymes. A hypothesis was also tested, according to which the toxicity of metal nanoparticles does not depend on their chemical nature. For this, the effect of nanoparticles of nickel, highly toxic for biota, and low-toxic iron was compared. The addition of equal amounts of nickel and iron (from 100 to $10,000 \mathrm{mg} / \mathrm{kg}$ ) had approximately the same comparable negative effect, whereas nickel is considered a significantly more toxic heavy metal than iron.

Keywords: Nanoparticles, Ecotoxicity, Pollution, Nickel, Iron, Ordinary Chernozem, Total Bacterial Count, Catalase Activity, Dehydrogenase Activity, Cellulolytic Activity, Azotobacter Abundance, Soil Phytotoxicity.

(C) RASĀYAN. All rights reserved
\end{abstract}

\section{INTRODUCTION}

At present the hazard of environmental pollution with nanoparticles of heavy metals increases due to the intensive development of nanotechnologies and increased production of nanomaterials, including those containing metals. According to estimations by Lux Research advisory company, the share of only three market segments of nanomaterials (power engineering, catalysts, and structural materials) amounts to $\$ 364.9$ million. Global cumulative consumption of nanomaterials exceeded $\$ 13$ billion. Nanopowder industry is one of the most developed commercial segments of nanomaterial market. Its average annual growth is $15 \%$. In natural terms of production, the market of nanopowders of pure metals is comprised of $16.5 \%$ of $\mathrm{Ni}$ and $\mathrm{Cu}$ powders. The top positions are also occupied by $\mathrm{Fe}, \mathrm{Al}, \mathrm{Zn}$, and $\mathrm{Ti}$. In Russia, as in the rest of the world, the production of oxide nanopowders is the most developed branch. In great demand are nanopowders of copper and nickel (annual production of at least $1500 \mathrm{t}$ ), aluminum and titanium (1350 t each), iron (1250 t) and other metals. ${ }^{1,2}$

Since nanomaterials are a new product type, characterization of their potential hazard for human health and environmental conditions is highly urgent.

Numerous researches are devoted to estimation of nanoparticle environmental impact. The influence of nanopowders on animals ${ }^{3-7}$, plants ${ }^{8-16}$, bacteria ${ }^{17-25}$, ferment activity ${ }^{26-29}$ has been studied. The environmental impact of nanopowders, including the impact on soil, should be studied in more details due to the inconsistency of estimations: some authors evidence safety of environmental pollution with

Rasayan J. Chem., 12(2), 549-553(2019)

http://dx.doi.org/10.31788/RJC.2019.1225058

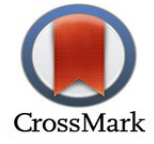


nanoparticles, and the others point to significant risks. However, the common agreement is that it is necessary to investigate into ecotoxicity of nanomaterials due to increased hazard on environmental pollution with technogenic nanoparticles as a consequence of the development of nanotechnologies and increased production of nanomaterials. The most urgent issues are the selection and/or development of evaluation methods of ecotoxicity of nanoparticles and determination of mechanisms of their toxicity.

This work is aimed at comparison of ecotoxicity of nickel and iron oxides and their nanoforms with regard to microorganisms, plants and chernozem fermentative activity in the model experiment.

\section{EXPERIMENTAL}

Soil pollution was simulated on a laboratory scale. Ordinary chernozem of southern European facie (North Azov area) was used. Chernozem is the most fertile soil in the world, it plays a significant role in foodstuff production. Soils were sampled in Botanic garden of the Southern Federal University, Rostovon-Don. $\mathrm{Ni}$ and $\mathrm{Fe}$ oxides $\left(\mathrm{Ni}_{2} \mathrm{O}_{3}\right.$ and $\left.\mathrm{Fe}_{2} \mathrm{O}_{3}\right)$ were used as toxicants.

Aiming at verification of the existing hypothesis that toxicity of metal nanoparticles actually does not depend on their chemical essence but only on the nanoparticle size, it has been interesting to compare the toxic impact of $\mathrm{Ni}$ and $\mathrm{Fe}$, since $\mathrm{Ni}$ is characterized by high toxicity with regard to biota ${ }^{30,31}$, and the $\mathrm{Fe}$ content in soil is higher and its toxicity is insignificant.

Conventional (not nano-) powders of nickel and iron oxides were used as references. Particle sizes of nickel and iron oxides in nanopowders were $10-20 \mathrm{~nm}$, and higher than $100 \mathrm{~nm}$ in conventional powders. The impact of various concentrations of metal oxides was tested: $100 ; 1,000 ; 10,000 \mathrm{mg} / \mathrm{kg}$. Maximum allowable concentration (MAC) of $\mathrm{Ni}$ in soil is $100 \mathrm{mg} / \mathrm{kg}^{30}$. Fe content in soil is not regulated due to its high level. In order to compare the toxicity degree of these two elements, Fe was added to soil in the same amount as Ni.

The soil was incubated in vegetation vessels at ambient temperature $\left(20-22^{\circ} \mathrm{C}\right)$ and optimum moisture content (60\% of water field capacity) with three replications. Samples for laboratory analysis were taken in ten days after pollution.

Laboratory analyses were performed according to methods commonly applied in biology, soil science, and ecology 32,33 . Total bacterial count in soil was measured by direct luminescence microscopy, Azotobacter abundance - by mud balls fouling on Ashby medium, catalase activity was determined by decomposition rate of hydrogen peroxide, dehydrogenase activity - by oxidation rate of triphenyl tetrazolium chloride, soil phytotoxicity - by seed germination and intensity of early sprout growth (root length).

\section{RESULTS AND DISCUSSION}

In the experiments, it was established that pollution of ordinary chernozem with $\mathrm{Ni}$, Fe oxides and their nanopowders resulted in deterioration of its biological condition (Table-1). As a rule, a significant decrease in all considered biological performances was observed. The decrease extent depended on the essence of pollutant and its concentration in soil. In most cases, the direct interrelation between pollutant concentration and the extent of deterioration of the considered soil properties was observed.

\section{Influence on Microbiological Performances}

Microbiological properties of soil state, such as total bacterial count and Azotobacter abundance, responded more significantly to nanoforms of nickel and iron oxides. Herewith, nickel nanoparticles exerted a higher toxic impact on microorganisms than iron nanoparticles.

Thus, when introducing iron and nickel oxides to the soil at a concentration of $100 \mathrm{mg} / \mathrm{kg}$, the total number of bacteria decreased to $92 \%$ and $80 \%$ of the control, respectively. A significantly greater decrease in this indicator is observed when introducing the same amount of nanoparticles of iron (76\% of the control) and nickel oxides (63\% of the control) to the soil. Nickel nanoparticles had a greater toxic effect on microorganisms than iron nanoparticles. Bacteria of the genus Azotobacter were more significantly affected by high concentrations $(10,000 \mathrm{mg} / \mathrm{kg})$ of nanoparticles of iron ( $66 \%$ of the control) and nickel oxides (75\% of the control) than ordinary iron (81\% of the control) and nickel oxides (78\% of the control). The high toxicity of nanoparticles with respect to bacteria was recorded by researchers for other metals as well $1^{21-27}$. 


\section{Influence on Soil Fermentative Activity}

$\mathrm{Ni}$ and Fe oxides and their nanoforms exerted higher influence on the fermentative activity of ordinary chernozem in comparison with their nanoparticles. For example, with the addition of $10,000 \mathrm{mg} / \mathrm{kg}$ of iron and nickel oxides, catalase activity decreases to $62 \%$ and $57 \%$ of the control, respectively, while iron nanoparticles decrease this indicator to $86 \%$ of the control and nickel nanoparticles- to $72 \%$ of the control. Ni oxide and its nanoform decreased catalase activity more significantly than Fe oxide and its nanoparticles. Catalase activity decreased with the increase in the pollutant concentration. In terms of influence on catalase activity in ordinary chernozem, the metal oxides ranked as follows: $\mathrm{Ni}>\mathrm{Fe}>\mathrm{Ni}$ (nano form) $\geq \mathrm{Fe}$ (nano form). The negative effect of heavy metal nanoparticles on the enzymatic activity of soils was also observed by other researchers. ${ }^{27-29}$

\section{Influence on Phytotoxic Performances}

The length of radish roots at a concentration of $100 \mathrm{mg} / \mathrm{kg}$ and $1,000 \mathrm{mg} / \mathrm{kg}$ was more significantly affected by the nanoforms of iron and nickel oxides. At the maximum studied concentration (10,000 $\mathrm{mg} / \mathrm{kg}$ ), on the contrary, they turned out to be less toxic than ordinary oxides. Ni and Fe oxides and their nanoforms influenced the germination of radish in different ways depending on the concentration of the substance. Iron oxide and its nanoform at a concentration of $100 \mathrm{mg} / \mathrm{kg}$ reduced this indicator about similarly: up to $83 \%$ and $87 \%$ of the control, respectively. Nickel nanoparticles at the same concentration were more toxic ( $77 \%$ of the control) than nickel oxide ( $98 \%$ of the control). With a further increase in the concentration, iron oxide and its nanoform have an approximately equal effect on the germination of radish (72\% and $71 \%$ of the control), and nickel oxide $(67 \%)$ is more toxic than its nanoform (83\%). At maximum concentration $(10,000 \mathrm{mg} / \mathrm{kg}$ ), iron oxide is more toxic than its nanoform (germination of radish is $65 \%$ and $74 \%$ of the control, respectively), and nickel oxide and its nanoform had an approximately equal effect ( $62 \%$ and $63 \%$ of the control).

Minimum phytotoxicity (if any) of nanomaterials ins oil was observed by other researchers. ${ }^{15,16,34,35}$ The considered biological performances such as activities of catalase and dehydrogenase, Azotobacter abundance, total bacterial count, radish root length were highly sensitive to soil pollution with nanoparticles of heavy metals. These performances should be reasonably applied with the aim of monitoring, diagnostics and standardization of chemical soil pollution with nanoparticles of heavy metals.

Table-1: Comparison of Ecotoxicity of Oxides of Nickel and Iron and their Nanoforms with regard to Microorganisms, Radish and Fermentative Activity of Chernozem

\begin{tabular}{|c|c|c|c|c|c|}
\hline \multirow[t]{2}{*}{ Element } & \multicolumn{5}{|c|}{ Amount of Pollutant } \\
\hline & Reference & $100 \mathrm{mg} / \mathrm{kg}$ & $1,000 \mathrm{mg} / \mathrm{kg}$ & $10,000 \mathrm{mg} / \mathrm{kg}$ & LSD05 \\
\hline \multicolumn{6}{|c|}{ Total Bacterial Count, $\%$} \\
\hline $\mathrm{Fe}$ & 100 & 92 & 69 & 57 & 9 \\
\hline $\mathrm{Ni}$ & 100 & 80 & 59 & 50 & 8 \\
\hline $\mathrm{Fe}($ nano) & 100 & 76 & 60 & 51 & 8 \\
\hline $\mathrm{Ni}($ nano) & 100 & 63 & 54 & 44 & 7 \\
\hline $\begin{array}{l}\text { LSD (Lowest } \\
\text { Significant } \\
\text { Difference) } 0.05\end{array}$ & & 7 & 8 & 9 & \\
\hline \multicolumn{6}{|c|}{ Azotobacter Abundance, \% Mud Balls Fouling } \\
\hline $\mathrm{Fe}$ & 100 & 98 & 91 & 81 & 11 \\
\hline $\mathrm{Ni}$ & 100 & 89 & 86 & 78 & 10 \\
\hline $\mathrm{Fe}($ nano) & 100 & 99 & 88 & 66 & 11 \\
\hline $\mathrm{Ni}($ nano) & 100 & 91 & 79 & 75 & 12 \\
\hline LSD 0.05 & & 9 & 11 & 10 & \\
\hline \multicolumn{6}{|c|}{ Catalase Activity, $\%$} \\
\hline $\mathrm{Fe}$ & 100 & 73 & 71 & 62 & 7 \\
\hline $\mathrm{Ni}$ & 100 & 72 & 64 & 57 & 6 \\
\hline $\mathrm{Fe}($ nano $)$ & 100 & 90 & 89 & 86 & 8 \\
\hline $\mathrm{Ni}$ (nano) & 100 & 83 & 78 & 72 & 7 \\
\hline
\end{tabular}


RASĀYAN J. Chem.

Vol. 12 | No. 2 |549 - 553| April - June | 2019

\begin{tabular}{|c|c|c|c|c|c|}
\hline LSD 0.05 & & 5 & 5 & 5 & \\
\hline \multicolumn{6}{|c|}{ Dehydrogenase Activity, \% } \\
\hline $\mathrm{Fe}$ & 100 & 81 & 80 & 74 & 7 \\
\hline $\mathrm{Ni}$ & 100 & 82 & 78 & 48 & 7 \\
\hline $\mathrm{Fe}($ nano) & 100 & 85 & 76 & 75 & 7 \\
\hline $\mathrm{Ni}$ (nano) & 100 & 86 & 83 & 63 & 9 \\
\hline LSD 0.05 & & 5 & 6 & 6 & \\
\hline \multicolumn{6}{|c|}{ Radish Root Length, \% } \\
\hline $\mathrm{Fe}$ & 100 & 77 & 75 & 46 & 8 \\
\hline $\mathrm{Ni}$ & 100 & 79 & 74 & 49 & 9 \\
\hline $\mathrm{Fe}($ nano) & 100 & 67 & 66 & 55 & 8 \\
\hline $\mathrm{Ni}$ (nano) & 100 & 71 & 62 & 61 & 8 \\
\hline LSD 0.05 & & 10 & 9 & 7 & \\
\hline \multicolumn{6}{|c|}{ Radish Germination, $\%$} \\
\hline $\mathrm{Fe}$ & 100 & 83 & 72 & 65 & 12 \\
\hline $\mathrm{Ni}$ & 100 & 98 & 67 & 62 & 15 \\
\hline $\mathrm{Fe}($ nano) & 100 & 87 & 71 & 74 & 15 \\
\hline $\mathrm{Ni}$ (nano) & 100 & 77 & 83 & 63 & 12 \\
\hline LSD 0.05 & & 9 & 10 & 8 & \\
\hline
\end{tabular}

\section{CONCLUSION}

Pollution of ordinary chernozem with $\mathrm{Ni}$, Fe oxides and their nanoparticles caused deterioration of its biological state. It has been established that microbiological performances (total bacterial count and Azotobacter abundance) are most influenced by nanoforms of $\mathrm{Ni}$ and Fe oxides. Soil fermentative activity (the activity of catalase and dehydrogenase) was more influenced by $\mathrm{Ni}$ and Fe oxides, not by their nanoparticles. Phytotoxicity performances (germination and radish root length) were influenced almost equally by $\mathrm{Ni}$ and $\mathrm{Fe}$ oxides and their nanoforms.

It has not been established that nanoparticles of $\mathrm{Ni}$ and Fe oxides $(10-20 \mathrm{~nm})$ are characterized by higher ecotoxicity than particles of $\mathrm{Ni}$ and Fe oxides of conventional sizes (100 $\mathrm{nm}$ and above).

Addition of equal amounts of nickel and iron (100-10,000 mg/kg) exerts approximately similar and comparable negative impact, whereas nickel is considered a significantly more toxic heavy metal than iron.

\section{ACKNOWLEDGMENT}

This work was supported by the Ministry of Education and Science of the Russian Federation (5.5735.2017/8.9) and the President of the Russian Federation (NSh-9072.2016.11, MK-326.2017.11).

\section{REFERENCES}

1. Marketingovoe Issledovanie Rynka Nanoporoshkov [Marketing Study of Nanopowders], Tekart Marketing Group, Moscow (2009).

2. Na poroge novykh tekhnologii [Challenging Technologies] (2011). http://fs.moex.com/files/2496/

3. R. D. Handy, G. Cornelis, T. Fernandes, O. Tsyusko, A. Decho, T. Sabo-Attwood, C. Metcalfe, J.A. Steevens, S.J. Klaine, A.A. Koelmans, N. Horne, Environmental Toxicology and Chemistry, 31(1), 15 (2012), DOI: $10.1002 /$ etc.706

4. E.J. Petersen, Q. Huang, W.J. Weber, Environmental Science \& Technology, 42, 3090 (2008), DOI: 10.1021/acs.est.5b05647

5. J. Unrine, P. Bertsch, S. Hunyadi, Bioavailability, Nanoscience and nanotechnology: Environmental and health impacts, John Wiley \& Sons, Hoboken, pp. 345-346 (2008), DOI: 10.1002/9780470396612.ch14

6. J.M. Unrine, O.V. Tsyusko, S.E. Hunyadi, J.D. Judy, P.M. Bertsch, J. Environ. Qual., 39, 1942 (2010), DOI: $10.2134 /$ jeq2009.0387

7. J.N. Meyer, C.A. Lord, X.Y. Yang, E.A. Turner, A.R. Badireddy, S.M. Marinakos, A. Chilkoti, M.R. Wiesner, M. Auffan, Aquatic Toxicology, 100(2), 140 (2010), DOI: 10.1016/j.aquatox.2010.07.016

8. Y. Ling, D. Yatts, Toxicology Letters, 158, 122 (2005), DOI: 10.1016/j.toxlet.2005.03.003 
RASĀYAN J. Chem.

Vol. 12 | No. 2 |549 - 553| April - June | 2019

9. V. Murashov, Toxicological Letters, 164, 185 (2006), DOI: 10.1016/j.toxlet.2006.03.002

10. X.M. Ma, J. Geiser-Lee, Y. Deng, A. Kolmakov, Science of the Total Environment, 408, 3053 (2010), DOI: $10.1016 /$ j.scitotenv.2010.03.031

11. D. Yatts, Y. Ling, Nanotechnology News, 3, 86 (2007).

12. H. Zhu, J. Han, J.Q. Xiao, Y. Jin, Journal Environment Monitoring, 10, 713(2008), DOI: 10.1039/B805998E

13. T.D. Deryabina, Bulletin of Orenburg state university, 12(131), 386 (2011).

14. L.V. Kovalenko, G.E. Folmanis, Biologicheski aktivnye nanoporoshki zheleza [Biologically active iron nanopowders], Nauka, Moscow (2006).

15. N. Zuverza-Mena, D. Martínez-Fernández, W. Du, J.A. Hernandez-Viezcas, N. Bonilla-Bird, M.L. López-Moreno, M. Komárek, J.R. Peralta-Videa, J.L. Gardea-Torresdey, Plant. Physiol. Biochem., 110, 236 (2017), DOI: 10.1016/j.plaphy.2016.05.037

16. I. Josko, P. Oleszczuk, E.J. Skwarek, Hazardous Materials, 331, 200(2017), DOI: 10.1016/j.jhazmat.2017.02.028

17. D.N. Williams, S.H. Ehrman, T.R.P. Holoman, Journal of Nanobiotechnology, 4(3), 771(2006), DOI: 10.1186/1477-3155-4-3

18. A.L. Neal, Ecotoxicology, 17, 362 (2008), DOI: 10.1007/s10646-008-0217-x

19. V.A. Terekhova, M.M. Gladkova, Pochvovedenie, 1, 82 (2014).

20. E.V. Yausheva, E.A. Sizova, I.A. Gavrish, S.V. Lebedev, F.G. Kayumov, Selskohozyaistvennaya biologiya, 52(1), 191(2017).

21. N. Karikalan, Rasayan J. Chem., 11(4), 1451-1457(2018), DOI: 10.31788/RJC.2018.1143068

22. A. Raj, R. Lawerence, J. Chem., 11(3), 1339(2018), DOI: 10.31788/RJC.2018.1132009

23. R. Sengodan, R. Ranjithkumar, K. Selvam, B. Chandarshekar, J. Chem., 11(1), 63(2018), DOI: 10.7324/RJC.2018.1111934

24. S. Hemalatha, M. Makeswari, J. Chem., 10(3), 838 (2017), DOI:10.7324/RJC.2017.1031800

25. P. Chakraborty, J. Adhikary, S. Chatterjee, B. Biswas, T. Chattopadhyay, J. Chem., 9(1), 77(2016).

26. B. Asadishad, S. Chahal, A. Akbari, V. Cianciarelli, M. Azodi, S. Ghoshal, N. Tufenkji, Environ. Sci. Technol., 52(4), 1908 (2018), DOI: 10.1021/acs.est.7b05389

27. C. Peyrot, K.J. Wilkinson, M. Desrosiers, S. Sauvé, Environ. Toxicol. Chem., 33(1), 115(2014), DOI: $10.1002 /$ etc. 2398

28. Y.J. Shin, J.I. Kwak, Y.J. An, Chemosphere, 88(4), 524 (2012), DOI: 10.1016/j.chemosphere.2012.03.010

29. A.N. Timoshenko, S.I. Kolesnikov, in Proceedings, International symposium: Biodiagnostics and quality estimation of natural environment: approaches, methods. criteria, and comparison references in ecotoxicology, GEOS, Moscow (2016).

30. A. Kabata-Pendias, Trace Elements in Soils and Plants, CRC Press, Boca Raton (2010), DOI: $10.1201 / \mathrm{b} 10158$

31. S.I. Kolesnikov, K.Sh. Kazeev, V.F. Val'kov, S.V. Ponomareva, Russian Agricultural Sciences, 36(1), 32 (2010).

32. D.G. Zvyagintsev (ed.), Metody pochvennoi mikrobiologii i biohimii [Methods of soil microbiology and biochemistry], MGU, Moscow (1991).

33. K.Sh. Kazeev, S.I. Kolesnikov, Yu.V. Akimenko, E.V. Dadenko, Metody biodiagnostiki nazemnykh ekosistem [Methods of biodiagnostics of surface ecosystems], Southern Federal University, Rostovon-Don (2016).

34. S. Asli, P.M. Neumann, Plant, Cell \& Environment, 32, 577(2009), DOI:10.1111/j.13653040.2009.01952.x

35. R. Doshi, W. Braida, C. Christodoulatos, M. Wazne, G. O'Connor, Environmental Research, 106, 296 (2008), DOI: 10.1016/j.envres.2007.04.006

[RJC-5058/2018] 